\title{
UDIO DJELA S FILOZOFSKOM TEMATIKOM U KNJIŽNOM FONDU SAMOSTANSKE KNJIŽNICE REDA KAPUCINA U VARAŽDINU PREMA KATALOZIMA IZ 1762. I 1944.
}

\begin{abstract}
Na temelju dvaju rukopisnih kataloga, Maccariusa Varsdinensisa iz 1762. i Tomislava Sagija iz 1944., autor istražuje udio knjiga s filozofskom tematikom u knjižnom fondu samostanske knjižnice reda Kapucina u Varaždinu s ciljem preciznog utvrđivanja kolikoće $i$ kakvoće specifične knjižnične građe, kako s obzirom na sadržaj djela, tako i na jezik, godište $i$ vrstu izdanja, uz posebnu nakanu utorđivanja jesu li u građi sadržane inkunabule ili rukopisi.
\end{abstract}

\section{UVOD}

U samostanskoj knjižnici franjevačkog reda Male braće Kapucina (Ordo Fratrum Minorum Capuccinorum- O.F.M.Cap.) u Varaždinu, osnovanoj odmah po njihovu dolasku 1699. ${ }^{1}$ i izgradnji samostana i biblioteke 1701.-1705. ${ }^{2}$, nalaze se dva izvrsno sačuvana kataloga iz 1762. i 1944. Osnovna nakana ovog istraživanja jest, prema

\footnotetext{
1 Najplauzibilniji historiografski izvori su: Ivan KUKULJEVIĆ SAKCINSKI, Varašdin- Kratki nacrt s gledišta historičkog, Zagreb, 1857.; TIVA, Varaždin, 1996., 20.; Rudolf HORVAT, Povijest grada Varaždina, Zavod za znanstveni rad HAZU- Varaždin, Varaždin, 1993., 215. - 217., 219. - 220.; Rudolf HORVAT, „Crtice iz varaždinske povijesti. Kapucinski samostan“, Naše pravice, god. X., br.36, 1 (1913).; Rudolf HORVAT, „Iz hrvatske prošlosti. Kapucinski samostan u Varaždinu“, Novosti, Zagreb, god. XX., br.248 (1926), 5.; Zapisnici hrvatskih sabora, Hrvatski državni arhiv u Zagrebu, Zagreb, knjiga IV, 218.-229.; Zapisnici poglavarstva slobodnog $i$ kraljevskog grada Varaždina, Sv. 9: 1685-1714. i Sv. 11: 1698-1703., Historijski arhiv Varaždin, Varaždin, 1990.

2 O povijesti i dolasku kapucina u Varaždin, njihovoj djelatnosti i znamenitim Kapucinima u povijesti, najbolje je konzultirati opsežno izdanje časopisa Radovi Zavoda za znanstveni rad HAZU Varaždin, br.1213/2001, izdanom nakon znanstvenog skupa povodom 300 godina prisutnosti Kapucina u Varaždinu.
} 
dvama katalozima, utvrditi udio djela filozofske tematike u ukupnom knjižničnom fondu samostanske knjižnice. Drugotna nakana je istražiti u kojem obimu je građa kataloga iz 1762. prisutna u katalogu iz 1944. odnosno danas. Potom, u pronađenoj građi utvrditi kvantitativne podatke o sadržaju, jeziku, godištu i vrsti izdanja, te naposljetku, o prisutnosti i udjelu hrvatskih autora.

Catalogus alphabeticus librorum Conventus Varasdinensis ab Anno MDCCLXII. je prvi i najstariji katalog i obuhvaća popis prikupljenih tiskanih izdanja do 1762., a pisan je rukom varaždinskog kapucina Maccariusa Varasdinensisa ili Makarija Varaždinca ${ }^{3}$. U pitanju je prvi pokušaj obradbe i dovođenja u red prikupljenog tiskanog knjižnog fonda vršenjem klasifikacije na 27 područja s jedne strane, kao i stjecanja cjelovit(ije) og uvida u to što knjižnica sve sadrži s druge. Za temu ovog rada najrelevantniji jest list kataloga naslovljen Q-Philosophi4 na kojem je dan popis 39 tiskanih izdanja s područja filozofije.

3 Maccarius Varasdinensis je svećenik iz Varaždina, pripadnik reda kapucina. U Nekrologiju slovenskih in hrvaških kapucinov (Ljubljana, interno izdanje, 1977., n.p) stoji tekst: „MAKARIJE, iz Varaždina, profesor filozofije i teologije, pisac, propovjednik (rođen u Varaždinu, umro i pokopan u Varaždinu, 2. I. 1783). U kapucinski red stupio 15. I. 1736. Istakao se kao propovjednik dok je boravio u Zagrebu i u Varaždinu. Posebno je zaslužan što je sistematski uredio knjižnicu kapucinskog samostana u Varaždinu za koju je napisao i katalog. Ostavio je u rukopisu slijedeća djela koja se nalaze u samostanskoj biblioteci u Varaždinu: Summa totius Cursus Theologici tradita a V.P. Jona Muraepontano, Lectore. Calamo expressa a V.P. Fre Meaccario Varasdinensi studente Capucino. Eius gloriosum illuxit principium die 18. martii 1744. Djelo je dovršeno 1748. godine u Grazu; Cursus Philosophicus Aristotelico-thomisticus. In lucem datus a R.P. Eligio Annanicensi Capue. Conscriptus a V. Fr. Maccario Varasdinensi eiusdem instituti studioso. Pisano god. 1735. (Uvidom u original rukopisa, treba napomenuti kako bi ovdje trebala stajati godina 1739., op.a.) To je uglavnom prijepis i prilagodba ogromnoga Eligijevog djela.; Ostavio je i udžbenik moralne teologije: Moralia brevi et clara methodo exhibita a P. Placido Capucino. Ad commodiorem usum et utilitatem confessariorum conscripta a P. Maccario Varasdinensi Capucino (sine anno). To je vrlo opširno djelo, praktično, za ispovjednike.“ U sačuvanim rukopisima Maccarius sebe potpisuje riječima „Maccario Varasdinensi Sacerdote Capucino“, no valja apostrofirati kako je tu nesumnjivo riječ o ablativu. O tome koji je najispravniji način njegova oslovljavanja autor je govorio u svom izlaganju u sklopu 24. Dana Frane Petrića i međunarodnog simpozija „S Petrićem u žarištu- hrvastki filozofi u europskom kontekstu“ 25.09.2015., gdje je održao izlaganje Rukopisi zabilježeni rukom kapucina Makarija Varaždinca u knjižnici kapucinskog samostana u Varaždinu počevši od 1739. (dostupno na http://www.hrfd.hr/documents/dfp-2015-publikacija.pdf, 139-141.). Nadalje, autor trenutno priprema tekst Maccarius Varasdinensis. Tri rukopisa u samostanskoj knjižnici reda kapucina u Varaždinu za časopis Prilozi za istraživanje hrvatske filozofske baštine.

4 Maccarius Varasdinensis, Catalogus alphabeticus librorum Conventus Varasdinensis ab Anno MDCCLXII. , Kapucinski samostan Varaždin, 1762., rukopis, 77. - 78. 
Drugi katalog je onaj iz 1944. pisan rukom jednog od najvećih hrvatskih teologa XX. stoljeća Tomislava Janka Šagi-Bunića ${ }^{5}$ kojim knjižnica dobiva svoj prvi katalog s kataloškim listićima za pojedine publikacije. Svoje gimnazijske dane tijekom ratnih godina 1943. i 1944., on je proveo u intenzivnom katalogiziranju odnosno stvaranju kataložnih jedinica za svaku pojedinu publikaciju unutar knjižnične građe samostanske knjižnice. Temeljito ih je obradio i klasificirao unutar 22 područja, među kojima je i filozofija, te rukom ispisao kataloške listiće sa sljedećim podatcima: pisac, naslov knjige, izdanje, opaska, sadržaj (klasifikacijska oznaka odn. specifično

5 Tomislav Janko ŠAGI-BUNIĆ (1923. Brodarovac kraj Varaždina- 1999. Zagreb) bio je hrvatski teolog, filozof i pisac, profesor i višekratni dekan na Katoličkom bogoslownom fakultetu u Zagrebu, (su)osnivač Glasa Koncila (1963.) i Kršćanske sadašnjosti (1968.) kao i Teološkog društva Kršćanska sadašnjost (1977.), provincijal i višekratni tajnik Ilirske kapucinske provincije u Hrvatskoj i Sloveniji, pokretač provincijskog lista "Folium Provinciae Illyriae Ordinis FF. Minorum Capuccinorum" te član prvog saziva Papinske komisije Kongregacije za nauk vjere. U osnovnoj školi Druškovec svršio je prva četiri razreda te školovanje nastavio u Varaždinu gdje je svršio veliku i malu maturu u ondašnjoj franjevačkoj gimnaziji, ujedno započevši život u kapucinskom samostanu. Svečane zavjete položio je u Zagrebu 1944. godine. Od 1943.-1949. studira teologiju na Katoličkom bogoslovnom fakultetu Sveučilišta u Zagrebu. Doktorsku disertaciju je obranio u rujnu 1951. na temu „Kristologija Prokla Carigradskog (434. - 446.). Prinos tumačenju kalcedonske dogmatske definicije (451.)“. U tom smislu valja istaknuti kako je Anto Barišić isti doktorat uredio i priredio za izdanje naslovljeno Kristologija Prokla Carigradskog (Kršćanska sadašnjost, Zagreb, 2009.). Šagi-Bunić je dao poseban doprinos sudjelovanjem na Drugom vatikanskom koncilu kao osobni teolog zagrebačkog nadbiskupa dr. Franje Šepera. U Rimu dovršava svoje kristološke studije, kojima rasvjetljava neka od temeljnih pitanja kršćanstva i stječe svjetski ugled monografijama: „Dua perfecta" et "due naturae“ in definitione Chalcedoenensi („dva potpuna“ i dvije "naravi“" u Kalcedonskoj dogmatskoj definiciji), (Rim, 1964), "Deus perfectus et homo perfectus“ (potpuni Bog i potpuni čovjek), (Rim, 1964.) i Problemata christologiae chalcedonensis (Kalcedonski kristološki problemi), (Rim, 1969.). Svoj teološki rad ponajvećma je posvetio konkretnoj liturgijskoj postkoncilskoj duhovnoj obnovi Crkve. Njegov teološki rad i djelovanje Tomislav Zdenko Tenšek dijeli na tri dijela: prvi dio od 1948. do 1965. u kojem rasvjetljava realnost istovremenog božanstva i čovještva osobe Isusa Krista; od 1959. do 1983. produbljuje temeljne koncilske misli i nastojanje oko teološko-pastoralne primjene Koncila u svakodnevnom životu Crkve, te 1983. do 1999. u kojem dominira govor o civilizaciji ljubavi koja snagom Duha Svetoga okuplja sve ljude odn. započinje govor o ekumenizmu tj. izgradnju „,civilizacije ljubavi“, koje doživljava svojevrsnu krunu rada izdanjem knjige Prema civilizaciji ljubavi (Kršćanska sadašnjost, Zagreb, 1998.). Najznačajnija njegova djela na hrvatskom jeziku su Izazov starih (Kršćanska sadašnjost, Zagreb, 1972.) , Povijest kršćanske literature I. Od početka do sv.Ireneja (Kršćanska sadašnjost, Zagreb, 1976.) te Euharistija u životu Crkve kroz povijest (Kršćanska sadašnjost, Zagreb, 1984.) u kojima daje značajne priloge na polju ranokršćanske literature crkvenih Otaca- apologetike i patristike te tumačenja Drugog vatikanskog koncila. Nadalje, u tri sveska Ali drugog puta nema (Kršćanska sadašnjost, Zagreb, 1969.) te Vrijeme suodgovornosti I. i II. (Kršćanska sadašnjost, Zagreb, 1981., 1982.) sabire svoje teološke članke s naglaskom na koncilsku problematiku. Također, dao je i priličan doprinos teološkoj dimenziji hrvatske državnosti djelima Crkva i domovina (Kršćanska sadašnjost, Zagreb, 1970.), Katolička Crkva i hrvatski narod (Kršćanska sadašnjost, Zagreb, 1983.) te Duhovno-moralna polazišta za budućnost Republike Hrvatske (Zagreb: Kršćanska sadašnjost, 1983.). Naposljetku, valja apostrofirati njegov doprinos opredjeljenju za ekumenizam programatskim člankom Śto sada s ekumenizmom (Kana, br. 1/1993., 14-15.) u kojem naznačuje da zadatak ekumenizma „potječe od Duha Svetoga i da nas je on pozvao na ekumenizam posredstvom drugog vatikanskog koncila. To je naša vjera." 
znanstveno polje), jezik i mjesto. Na taj je način utemeljio i omogućio daljnji razvoj knjižnice.

Nakana autora jest na temelju podataka iz dva kataloga odrediti kolikoću i kakvoću prisutnosti djela filozofskog karaktera i tematike unutar ukupne knjižnične građe samostanske knjižnice reda Kapucina u Varaždinu ${ }^{6}$, s posebnim naglaskom i osvrtom na djela hrvatskih autora odnosno djela na hrvatskom jeziku. Knjižničnu građu, osim prema temi ili sadržaju, promatra i obrađuje s aspekta jezika na kojem je pisana, stoljeća i(li) godišta i vrste izdanja naznačujući je li riječ o tiskanom djelu ili rukopisu odnosno inkunabuli.

Kao pripomoć autor koristi tekstove Zdenka Tenšeka, Bone Zvonimira Šagija i Tomislava Janka Šagi-Bunića, Mirka Kemiveša, Jure Šarčevića i Rudolfa Horvata o dolasku, djelatnosti i razvoja kapucinskog reda u Varaždinu ${ }^{7}$ Tematski gledano, među njima potpuno relevantan je jedino tekst Kapucinska knjižnica u Varaždinu8 Bone Zvonimira Šagija, ujedno i jedini objavljeni tekst posvećen ovoj knjižnici do sada. Bono Šagi je nastojao notificirati opće podatke o knjižnici, posebice o njenom ustroju i razvitku te prikupljanju knjižnog fonda i smještaju knjižnog blaga. Također, doduše vrlo općenito, naznačio je i što knjižnica posjeduje. Uz sve svoje mane, posebice manjka (preciznijih) referenci i podataka odnosno sustavnijeg i sistematiziranijeg sažimanja i prikaza, tekst je vrijedan pokušaj stvaranja temelja za buduća istraživanja, ali i za razvoj knjižnice kao takve.

Osim tih, autor se referira i na dva kraća neobjavljena teksta: rukopis Katalog inkunabula $i$ knjiga tiskanih do godine 1536., s detaljnim komentarima i opaskama, Tomislava Šagi iz 1944. ${ }^{9}$ koji sadrži popis 60 svezaka, od čega 16 inkunabula, te Rukopisi Kapucinske knjižnice u Varaždinu Bone Zvonimira Šagija iz 2001. koji sadrži popis 23 rukopisna primjerka.

\footnotetext{
6 Autor je imao izlaganje o provedenom istraživanju 26.05.2015. na Institutu za filozofiju u sklopu međunarodnog simpozija Hrvatska filozofija: jučer, danas, sutra na temu: „Udio djela s filozofskom tematikom u knjižnom fondu samostanske knjižnice reda Kapucina u Varaždinu“, (sažetak dostupan na http://www.ifzg. hr/poveznice/Simpozij-Hrvatska_filozofija_i_znanost-knjizica_sazetaka.pdf, 36. - 37.). Također, u sklopu projekta "Hrvatska filozofija i znanost” Instituta za filozofiju, autor je imao izlaganje na temu "Knjižnica kapucinskog samostana u Varaždinu- povijest i filozofija.»

7 Radovi Zavoda za znanstveni rad HAZU Varaždin, br.12-13 (2001.), izdanom nakon znanstvenog skupa povodom 300 godina Kapucina u Varaždinu; Rudolf HORVAT, Povijest grada Varaždina, Zavod za znanstveni rad HAZU, Varaždin, 1993., 215. - 217., 219. - 220.

8 Radovi Zavoda za znanstveni rad HAZU Varaždin, br.8-9 (1996.), 103. - 109.

9 Rođen kao Janko Šagi, do 1960. i odlaska na II. Vatikanski koncil koristio je isključivo redovničko ime Tomislav i rođeno prezime Šagi.
} 


\section{SAMOSTANSKA KNJIŽNICA NA ČETIRI LOKACIJE}

Kapucinski samostan i pripadajuća crkva sv. Trojstva počinju svoje djelovanje svečanim obredom posvećenja 1705., a s njima i knjižnica ustrojena za potrebe članova reda. Prostorija prvotne knjižnice danas više nije sačuvana $u$ izvornom obliku i dimenzijama, već je njen duži pokrajnji zid okrenut unutrašnjosti samostana srušen i spojen s okolnim prostorom poradi praktičnih razloga. Prilikom izgradnje samostana i crkve, time i izradi prostora knjižnice, u potpunosti su poštivane smjernice i upute iz Constitutiones kapucinskog reda izdanih od strane pape Urbana VIII. 1643. ${ }^{10}$ One propisuju prostorne dimenzije, po kojima maksimalni gabariti po dužini i širini ne smiju biti veći od $234 \mathrm{~cm}$ ili 9 pedalja, uz naznaku kako 1 pedalj iznosi 26 centimetara, te po visini ne veći od 10 pedalja ili $260 \mathrm{~cm}$. Vrata su mogla biti visoka maksimalno 7 pedalja ili $182 \mathrm{~cm}$ te široka 2,5 pedlja ili $65 \mathrm{~cm}$. Propisane poštivane dimenzije prozora na sobama iznosile su 2,5 pedlja ili $65 \mathrm{~cm}$ visine i 1,5 pedlja ili $39 \mathrm{~cm}$ širine, te su istom obliku sačuvane do danas. ${ }^{11} \mathrm{U}$ tom smislu, radi lakše izmjere, $\mathrm{u}$ Constitutiones je na posebnoj stranici dan prikaz polovice pedlja $(13 \mathrm{~cm}) \mathrm{u}$ obliku pravokutnika unutar kojeg je tekst "misura del mezo palmo“. ${ }^{12}$ Kapucinima je odobrena izgradnja 28 soba (ćelija) te bolesnička kapela s dva prozora i 4 bolesničke sobe, od kojih je jedna određena za samostansku biblioteku ${ }^{13}$, sukladno odredbi konstitucije u kojoj stoji:

„...da bi (redovnici, op.a.) bolje opsluživali siromaštvo i iz srca isključili osjećaj posebnosti, naređuje se da u svakom našem samostanu bude posebna prostorija srednje veličine gdje se skladište Sveto Pismo, knjige svetih učitelja teologije i sve ostale koje su potrebne..."14

Također, postojala je i prostorija za školu, ispod bolesničkih soba, a samostan je bio i sjedište novicijata i studija. ${ }^{15}$

10 Constitutioni De Fratri Minori Capuccini di S. Francesco, Aprouate, e confermate da N S Papa Urbano VIII (Roma: Nella Stamparia della Reuer.Cam.Apost., 1643.), prvo izdanje, 32., 26., 53.; Constitutiones, ordinis fratrum minorum Capuccinorum, decursu promulgatae, vol.I Constitutiones antiquae (1529.-1643.), (Curia generalis OFMCap, Romae, 1980.), 598., 602., 619.

11 Constitutioni (1643), 32. - 33. (Constitutiones, 1980., 598. - 599.); usp. Mirko Kemiveš, „Dolazak kapucina u Varaždin i znameniti kapucini tijekom 300 godina varaždinskog samostana", Radovi Zavoda za znanstveni rad HAZU Varaždin, br.12-13/2001, 128. - 129.

12 Isto, 636.

13 Usp. Mirko KEMIVEŠ, „,Dolazak kapucina u Varaždin i znameniti kapucini tijekom 300 godina varaždinskog samostana", Radovi Zavoda za znanstveni rad HAZU Varaždin,br.12-13/2001, 129.

14 Constitutioni (1643.), 53. (Constitutiones (1980.), 619.

15 M. KEMIVEŠ, „Dolazak kapucina u Varaždin i znameniti kapucini tijekom 300 godina varaždinskog samostana", 130. 
Bibliotecha iz 1830. godine je izgrađena s vanjske strane sjevernog dijela samostana za potrebe uspješnijeg očuvanja knjižnog fonda, u svrhu čega je izgrađen i poseban strop od ciglom zidane bolte, dok ostatak samostana ima drveni. Prostor i danas služi svojoj izvorno zamišljenoj svrsi, uz napomenu kako se u njoj čuvaju sva najvrjednija izdanja samostanske zbirke iz 15., 16. i 17. stoljeća te mali dio iz 18. stoljeća, poput rijetkih (i) prvih izdanja, rukopisa i 16 inkunabula. Među njima, ona najvrjednija smještena su u dodatan sef nabavljen upravo za tu svrhu. Ipak, ni nadograđeni prostor uskoro nije bio dostatan zbog čega se javila potreba za dugoročno efikasnijim rješenjem koje će anticipirati i daljnju ekspanziju knjižnog fonda u relaciji s adekvatnim prostornim zahtjevima.

\section{I\& B IBLIOTHECA $\approx$}

Slika 1. Natpis iznad ulaza u samostansku knjižnicu iz 1830. reda kapucina u Varaždinu

Podrumska knjižnica iz 1983. u prostoru negdašnjeg Đačkog konvikta Sv. Josipa i sadašnjeg sjemeništa, nakon adaptacije suterena zgrade od 1979. do 1983., postala je treća lokacija samostanske knjižnice. Inicijativa je to tadašnjeg župnika Bone Zvonimira Šagija, koji je smatrao kako je time konačno postignuto kvalitetno rješenje kojim se "dobilo dosta prostora i za budući razvoj“. ${ }^{16}$

Ipak, ni taj prostor nije (bio) dostatan, te je oformljen i četvrti prostor s djelima prikupljenim nakon 1983. u kojem se u čuvaju uglavnom recentn(ij)a izdanja.

$\mathrm{S}$ druge strane, što se tiče katalogiziranja knjižnog fonda, ono je vršeno u pet navrata, od kojih su najvažnija i najvrjednija dva istaknuta u uvodu. Prvi katalog je rukopis iz 1762. u kojem je Maccarius Varasdinensis popisao 1958 knjiga $^{17}$. Sljedeća katalogizacija je vršena, od strane nepoznatih autora, između 1880. i 1890., te je njome utvrđeno stanje od 2309 naslova. Katalogizacija iz 1909.-1911. o. Jakoba Brlića dokaz je daljnjeg povećanja knjižnog fonda s 3980 pobrojanih naslova, premda nije obradio kompletan knjižnični fond. ${ }^{18}$ Tomislav Šagi katalogizacijom 1943./1944.

16 Bono Zvonimir ŠAGI, „Kapucinska knjižnica u Varaždinu“, Radovi Zavoda za znanstveni rad HAZU Varaždin, br.8-9/1996, 107.

17 Usp. Isto, 107. Nejasno je zašto i kako je Bono Zvonimir Šagi u svom radu došao do pogrješne brojke od 1820 primjeraka.

18 Isto, 105.: „,ali i taj popis nije bio potpun, jer nije bilo dovoljno mjesta, pa su knjige ostajale na nesređenim hrpama." 
dao je ogroman prinos detaljnom obradbom i klasifikacijom građe, kao i izradom rukom čitko ispisanih kataloških listića. Posljednja katalogizacija započeta je 1979. i nije dovršena, tek je njen inicijator župnik Bono Zvonimir Šagi ustvrdio kako je do 1996. izdvojeno oko 4000 svezaka iz razdoblja od 15. do 18. stoljeća te kako je do iste godine fond narastao na oko 14000 bibliografskih jedinica. ${ }^{19}$

Danas knjižnica vapi za novom i temeljitom obnovom, kako prostora, tako i obradbe knjižnične građe, te posebice- njezinu digitalizaciju.

\section{KATALOG MACCARIUSA VARASDINENSISA IZ 1762.}

Katalog je rukopis kapucina Maccariusa Varasdinensisa, svećenika kapucinskog samostana u Varaždinu. Katalog ima oblik knjige formata 150×200 mm, ukoričenog u tvrdi kožni uvez sa 112 stranica bez izvršene paginacije. Broj stranica je bio i veći, jer se vidi jasan trag trganja stranica iz kataloga nakon zadnje stranice na kojoj je dan popis 66 djela na hrvatskom jeziku. Uz korice su i dvije zaštitne stranice, s time da se na drugoj nalazi samostanski pečat s natpisom „BIBLIOTEKA O. O. KAPUCINA VARAŽDIN“, koji je stavljen tijekom posljednje katalogizacije. Na trećoj stranici nalazi se naslov u 6 redaka:

\section{„CATALOGUS/ALPHABETICUS / LIBRORUM / CONVENTUS / Varasdinensis / ab Anno MDCCLXII".}

Na sljedećoj stranici odnosno na poleđini istog lista u 5 redaka stoji:

„Dispositu / A.P.F.Maccario / Varasdinensi / Sacerdote / Capucino.“

Nakon toga, slijedi popis knjiga. Maccarius prikupljenu građu od 1958 primjeraka, isključivo tiskanih djela, klasificira u 27 predmetnih područja koja su označena velikim slovima abecede, počevši od $A$ pa sve do $t Z$, koje slijedi nakon $Z$, s nekoliko posebnosti: nakon $S$ slijedi $S S$; unutar područja označenih velikim slovom $A, H, M, T$ su sadržana podpodručja označena malim slovima $a, h, m, t$, dok su unutar područja $L, X$ i Y sadržana po dva podpodručja označena s $l$. i ll., X.a. i X.A. odnosno y.a. i y.b. Nadalje, preko svake stranice se prostire tablica čije su margine crvene boje i imaju dva stupca. U lijevom, mnogo širem, sadržani su prilično šturi podatci o popisanim bibliografskim jedinicama, uglavnom tek ime autora i djelo te broj toma, dok se s desne strane nalazi stupac koji je puno uži i sadrži samo redni broj djela unutar

19 Isto, 106. 


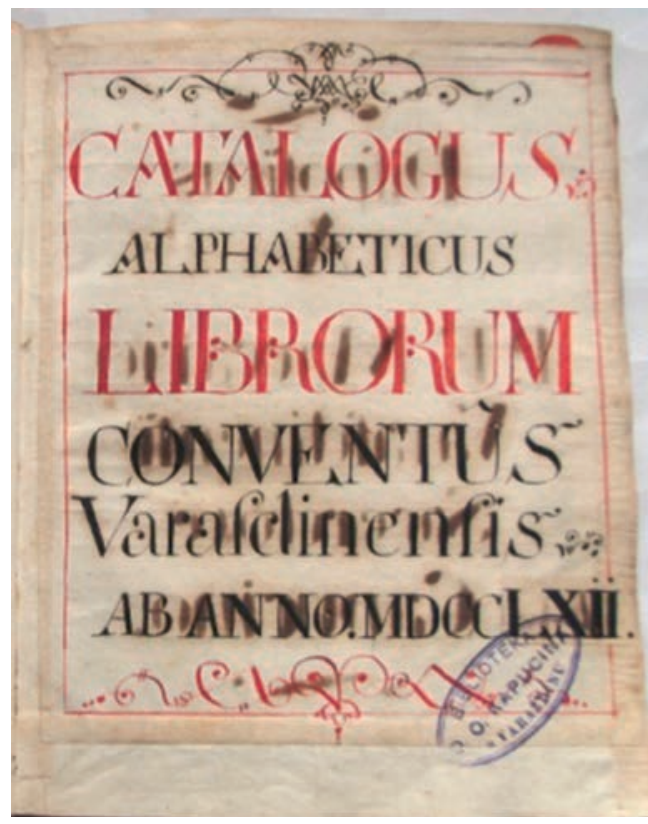

Slika 3. Naslovna stranica kataloga iz 1762.

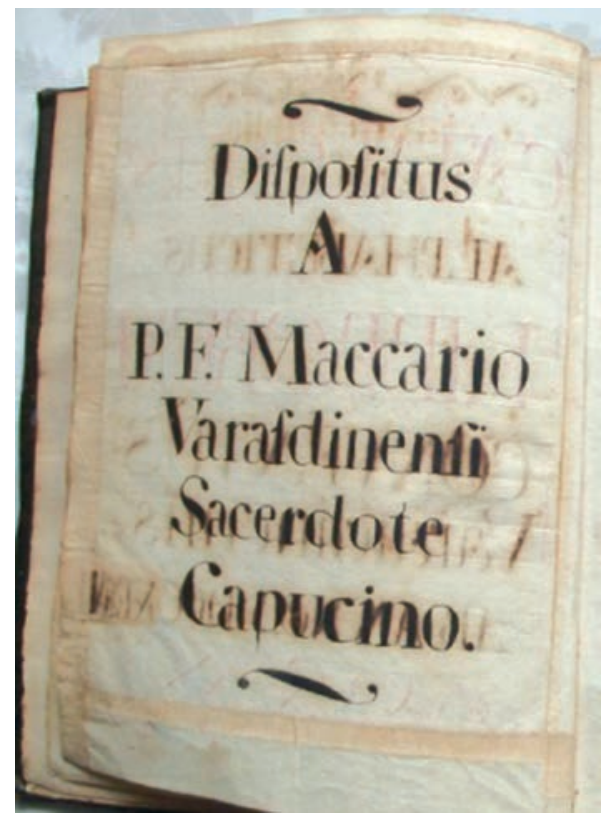

Slika 4. Poleđina naslovne stranice kataloga iz 1762.

područja. Tek nakon uporedbe sa Šagijevim katalogom postaje jasan obim navedenog. Primarno fakt kako nerijetko imena autora i djela nisu potpuna, s time da je za 9 popisanih djela naveden samo naslov bez navođenja autora. Također, podatci o izdavaču, mjestu i godini izdanja uopće nisu navedeni. Zbog svega iznesenog, može se ustvrditi da bez kataloga Tomislava Šagija ${ }^{20}$ iz 1944. nije moguće (preciznije) rekonstruirati o kojim se djelima, autorima i izdanjima radi.

Predmetna područja unutar kataloga prema Maccariusovoj klasifikaciji su sljedeća:

„A. Sacra Biblia / a- Cocordantiae / B. SS. Patres / C. Expositores / D. Authores Praedicabiles./ E. Conřes Lai: 40stae, Dncles, \& Festivi. / F. Contres Germ: 40stae, Dnicls, \& Festivi. / G. Contres Itali 40stae, Dnicles, \& Festivi. / H. Vitae SSrum Lingvar.Div: / h-Minusc: Libri Meditationum. / I. Chathechistae Divers: Ling. / J. Controversiste. / K. Afcetae Itali. / L. Afcetae Latini. / 1.-Minusc: Afcetae Germani. / 11. Historiae Spriles / M. Historiae Profanae. / m-Libri Concernentes Ordinem S.

20 Katalog Kapucinske knjižnice u Varaždinu, izradio Tomislav ŠAGI, Kapucinski samostan Varaždin, Varaždin, 1944., odnosno Tomislav ŠAGI, Katalog Inkunabula i knjiga tiskanih do godine 1536.,Kapucinska knjižnica samostana u Varaždinu, Varaždin, 1944., rukopis. 
Francisci / N. Iuris Canonici / O. Theolỏgi Speculátivi / P. Theológi Morales / Q. Philosophi / R. Rhetores. / S. Pỏétae / SS- Doctrinales. / T. Humanitae / t- Rubriciste ,\& Paroch: Ínft: / U. Libri Ondinandor./ W21. Juris Civilis / X. Dictionaria / X.a. Regulae Ordinum / X. A.- Medici , \& Pharmaceu / Y. Pollitico: Miscellanéi. / y.a. Libri Exercitiorum. / y. b.- Libri Infirm:\&Bene: / Z. Libri Carniolici / tZ. Libri Cróatici + Pars Íl. Continuatio Í". ${ }^{22}$

Popis 39 djela s područja filozofije nalazi se na stranicama 77. i 78. kataloga pod oznakom $Q$. Philosophi. Na prvoj od dvije stranice je dan popis do rednog broja 23, a na drugoj ostatak ${ }^{23}$, s time da je u zagradi naveden redni broj iz desnog stupca. Također, treba notirati kako je nakon rednog broja 29. ubačena opaska „NB. Trutina Doctrina Carthesÿ Sub Nr'o (numero,op.a.) 16. 2do'“ kojom se upućuje na djelo pod rednim brojem 16 u kojem je sadržana Kartezijeva doktrina o ravnoteži. S druge strane, pod rednim brojem 16. također postoji opaska „In alia'ple folÿ“ što je skraćenica od in alia plurime folii odnosno naznaka kako u drugima (izdanjima) ima više stranica. Evo i popisa djela:

„Liber Seneca (1.) / Aristotelista Stagyrita Libri 8. (2.) / Mastoius cursus physhc'us. Tom. 1. et 2. Sl' (3.) / Ejusdem ${ }^{24}$ Tom 3. (4.) / Ejusdem Tom 4. et 5. Sl' (5.) / Romoser Logica Thm'stc'a (6.) / Aller Pars 1. (7.) / Ejusdem Pars 2. et 3. Simul. (8.) / Marci ã Bándunio Paradisus phlsphc'us. (9.) / Toleti Logica. (10.) / Gervasÿ Logica. (11.) / Ejusdem 2do'. (12.) / Ejusdem phsc'a 'nalis. (13.) / Ejusdem phsc'a ptr'lis. (14.) / Compendium Dialectica. (15) / Iter Carthesÿ per Mundum. NB (nota bene, op.a.) In alia'ple folÿ (16.) / Concl. phs'phus cum annex. Sent. (sentenciae) Corn. (Cornelie) Taciti (17.) / Philognomia scholli (18.) / Hortulus Phyhc'o Thstc'us. (19. $)^{25}$ / Geographiá geom. (20.) / Cosmographia. (21.) / Compendium Geographia. (22.) / Rudimenta Mathoseos ac Geometria. (23.) / De Atmosphera.(24.) / Sinopsis globi Terraquei. (25.) / Ferrari Solghy Antonÿ Phylo'hia S. Tomis Distá (26.) / Redlhamer Logica, et Metaphisicá 2nda sub Nro'. eodem. (27) / Ejusdem physica pars 1. et 2nda. (28.) / Ma'yr philosophia idem 2ndo' sub eodem Nro'. (29.) / NB. Trutina Doctrina Carthesÿ Sub Nr'o (numero) 16. 2do'/ Bernardi a Bononia (Bologna, op.a.) tom 3 i 4.

21 Slovo V je jednostavno preskočeno, te se prjelazi na W. koje stoji na mjestu V.

22 Maccarius, Catalogus alphabeticus librorum Conventus Varasdinensis, 4. - 112.

23 Ovdje se mora istaknuti svesrdna i nesebična pomoć župnika kapucinskog samostana u Varaždinu mr. sc. Mirka Kemiveša OFM Cap, vrhunskog stručnjaka i vrsnog poznavatelja kapucinskog reda, samostana i knjižnice u Varaždinu, te ogromna zahvalnost za sate provedene uz stranice kataloga i pokušavanje rekonstruiranja Maccariusova rukopisa.

24 Doslovno: isti autor. Ta se oznaka pojavljuje u katalogu točno 10 puta; skraćenica physhc'us označava phylosophicus, dok skraćenica Sl' označava simultano (istovremeno, zajedničko) sadržavanje 1. i 2. dijela u jednoj knjizi, op.aut.

25 Phyhc'o Thstc'us označava Phylosophico Tomisticus. Dakle radi se o autoru Hortulusu koji je napisao Filozofiju Tomizma. 
(30.) / Kheell Josephi in 4 tom (31.) / Heimbach tom.2 (32.) / Ma'yr philosophia peripathetica tom .1 (33.) / ejusdem Tom.2. (34.) / ejusdem. Tom. 3. (35.) / ejusdem. Tom. 4. (36.) / Jasklinsky instiuttiones logicae (37.) / Prima Elementa Arihum. Algebra, geom. Trigon. (38.) / ๑ Gablinga Balrici Anima Ro’alis.(39.)“26

Primjetno je da Maccarius prilikom popisivanja djela koristi niz različitih skraćenica poput primjerice Thm'stc'a kada se želi reći Thomistica, physhc'us, phs'phus, phlsphc'usi phsc'a za phylosophicus, potom Phylo'hia za Phylosophia, Phyhc'o Thstc'us za phylosophico Thomisticus, geom. za geometria, Nr'o za numero, Concl. za Conclusio, Sent. za sentencie, Corn. za Cornelie, S.J. za Societas Jesu odn. isusovac te naposljetku $S l^{\prime}$ za simul. odnosno zajedno. Nije najjasnije zašto je Maccarius pribjegavao takvim rješenjima i u tolikoj mjeri, posebice kada time nije dobio ništa na uštedi prostora odnosno (tada skupocjenog) papira.

Mnogo važnije pitanje jest zašto su prikupljana i čemu su služila djela s područja filozofije. Odgovor postaje evidentan kada se konzultiraju Generalne ordinacije reda kapucina iz 1757., koje je donio Stjepan iz Ziegenhalsa a potvrdio papa Benedikt XIV. Između ostalog, u sklopu generalne reforme studija, one propisuju kako će izgledati trogodišnji obligatoran studij filozofije:

„...u prvoj godini podučavala se gramatika i logika, u drugoj godini osam knjiga fizike te pojmovi iz geometrije, četiri knjige o svijetu, nebu i počelima, a u trećoj godini, dvije knjige o rađanju i raspadanju, četiri knjige o atmosferskim pojavama, tri o duši te metafizika..." ${ }^{27}$

Naime, Maccariusov popis prati potrebe studija filozofije te su knjige očito nabavljane iz tovrsnih praktičnih razloga. ${ }^{28}$ Ono što upada u oči jest prirodoslovno- matematička obojenost studija odnosno činjenica kako su fizika, kozmologija, astronomija, geografija, matematika i geometrija sastavni dio filozofske naobrazbe i studija. U pitanju je inklinacija s početka 18. stoljeća, pridavanja veće važnosti i pozornosti prirodnim i egzaktnim znanostima:

„...budući da ne vrijedi ignorirati ono što se u ovom našem prosvjetiteljskom dobu uči u svim krajevima, lektori moraju upoznati svoje učenike s najnovijim suvremenim učenjima, pobijati ih ili ih predstavljati u obliku suprotnog mišljenja..."29

Stoga je potpuno logično da Maccariusov popis sadrži 12 djela takve tematike, $\mathrm{u}$ katalogu navedenih pod rednim brojevima 13., 14., 16., 20., 21., 22., 23., 24., 25., 28., 38. i 39.

26 Maccarius, Catalogus alphabeticus librorum Conventus Varasdinensis, 77. - 78.

27 Fra Mariano D’ALATRI, OFMCap., Kapucini, povijest jedne franjevačke obitelji, Kršćanska sadašnjost, Zagreb, 2010., 75.

28 Usp. Isto, 77.

29 Lazaro IRIARTE, Povijest franjevaštva, Kršćanska sadašnjost, Zagreb, 2013., 347. 
Nadalje, gledano s aspekta sadržaja djela, između ostalih, u knjižnici su sačuvane 4 različite logike, 4 primjerka filozofsko-tomističke sume, 5 peripatetičke filozofije oslonjene na nauk Duns Scota i 4 različita cursus philosophicus, te tek 1 originalno djelo nekog od antičkih pisaca- Seneke.

Naposljetku, ostaje pitanje koliko je djela iz Maccariusova kataloga još uvijek prisutno u knjižnici s jedne strane, te mogu li se ustanoviti točni podatci o tim djelima: autor, naslov, izdanje i godina s druge? Provedeno istraživanje, koje pruža odgovore na takva pitanja, najpreglednije se može izložiti tabličnim usporednim prikazom kataloških podataka koje sadrže katalozi iz 1762. i 1944.

Tablica 1. Usporedni prikaz popisa djela s područja filozofije iz kataloga Maccariusa Varasdinensisa (1762) i Tomislava Šagija (1944).

\begin{tabular}{|c|c|}
\hline $\begin{array}{l}\text { Maccarius Varasdinensis } \\
\text { Katalog iz } 1762 .\end{array}$ & $\begin{array}{l}\text { Tomislav Šagi } \\
\text { Katalog iz } 1944 .\end{array}$ \\
\hline Liber Seneca. & $\begin{array}{l}\text { Seneca Lucius Cordubensis, Opera, izdanje Tarvisii per Bernardum de } \\
\text { Colonia, 1478. Inkunabula' }\end{array}$ \\
\hline Aristotelista Stagyrita Libri 8. & $\begin{array}{l}\text { Aristotel Stagyrita, Physicae Libri VIIII.I. Argiropilo interprete, cum ad } \\
\text { notationibus } 8 \text { comentariis, izdanje In Augusta Vindelica, } 1578 .\end{array}$ \\
\hline $\begin{array}{l}\text { Mastoius cursus physhc'us. Tom. } \\
\text { 1. et 2. Sl' }\end{array}$ & \multirow{3}{*}{$\begin{array}{l}\text { Fr. Thomas a J. Joseph,et Fr. Petrus a S. Catharino, franjevci, Cursus } \\
\text { Philosophicus ad usum Stud. Ordinis Minorum ad mentem subtilis Scoti, } \\
\text { Venetiis, } 1732 .\end{array}$} \\
\hline Ejusdem. Tom. 3. & \\
\hline Ejusdem. Tom. 4. et 5. Sl' & \\
\hline Aller Pars 1. & \multirow{2}{*}{$\begin{array}{l}\text { Aler p.Paulus, Philosophia Tripartita ad mentum Doctrio Angelici, } \\
\text { Coloniae } 1710-1724 .\end{array}$} \\
\hline Ejusdem. Pars 2. et 3. Simul. & \\
\hline $\begin{array}{l}\text { Marci ã Bándunio Paradisus } \\
\text { phlsphc'us. }\end{array}$ & $\begin{array}{l}\text { Marcus p Baudunius, Paradisus Phiosophicus ad mentem doctoris Angelici, } \\
\text { seraphici, subtilis, Massiliae, } 1664 .\end{array}$ \\
\hline Toleti Logica. & $\begin{array}{l}\text { Toletus Franciscus, Comentaria in universam Aristotelis logicam, } \\
\text { izdanjeColoniae Agrippinae, } 1589 .\end{array}$ \\
\hline Gervasÿ Logica. & \multirow{4}{*}{$\begin{array}{l}\text { p. Gervasius Brisacensis capucino, Cursus philosophicus Logica, izdanje } \\
\text { Coloniae Agrippinae, 1699. i p. Gervasius Brisacensis capucino, Cursus } \\
\text { philosophicus, Physica particularis et Metaphisica, izdanje Coloniae } \\
\text { Agrippinae, } 1734 .\end{array}$} \\
\hline Ejusdem 2do'. & \\
\hline Ejusdem phsc'a 'nalis. & \\
\hline Ejusdem phsc'a ptr'lis. & \\
\hline Compendium Dialectica. & $\begin{array}{l}\text { Horneius Conradus Theologus, Compendium Dialectices, Helmaestady, } \\
1642 .\end{array}$ \\
\hline $\begin{array}{l}\text { Ferrari Solghy Antonÿ Phsophia } \\
\text { S. Tomis Dista' Ejusdem physica } \\
\text { pars 1. et 2nda }\end{array}$ & $\begin{array}{l}\text { Ferrarus fr. Joseph. Antonin de Mondoetia, konvent., Philosophia } \\
\text { peripatetica ad menteno Joannis Dunsi Scoti, Venetiis, } 1754 .\end{array}$ \\
\hline $\begin{array}{l}\text { Redlhamer Logica, et Metaphisicá } \\
\text { stac 2nda sub Nro' eodem. }\end{array}$ & \multirow{2}{*}{$\begin{array}{l}\text { Redlhamer Josephus S.J. (Societas Jesu, Isusovac, op.a.), Philosophie tract. } \\
\text { I. sen } \\
\text { Philosophia Naturalis, izdanje Viennae Austriae 1752. }{ }^{2}\end{array}$} \\
\hline Ejusdem Physica Pars 1. Et 2nda. & \\
\hline
\end{tabular}




\begin{tabular}{|c|c|}
\hline $\begin{array}{l}\text { Maccarius Varasdinensis } \\
\text { Katalog iz } 1762 .\end{array}$ & $\begin{array}{l}\text { Tomislav Šagi } \\
\text { Katalog iz } 1944 .\end{array}$ \\
\hline $\begin{array}{l}\text { Máyr philosophia.Idem 2ndo' sub } \\
\text { eodem Nro'. }\end{array}$ & $\begin{array}{l}\text { Mayr p. Petrus Paulus S.J., Philosophia rationalis et naturalis, Graecii, } \\
\text { 1752. }\end{array}$ \\
\hline $\begin{array}{l}\text { Bernardi ã Bononia (Bologna, } \\
\text { op.a.) Tom. 3. in 4do'. }\end{array}$ & $\begin{array}{l}\text { Fr. Bernardo a Bononia, capuccino, Institutio philosophica, ad mentem } \\
\text { Aristoteliset Duns Scoti, Venetüs } 1766 .\end{array}$ \\
\hline Khéell Josephi. in 4do'. & $\begin{array}{l}\text { Khell Josephus, S.J., Physica ex recentiorum observationibus accomodata } \\
\text { noibus academias, Viennae Austria, } 1751 .^{3}\end{array}$ \\
\hline Heimbach. Tom.2. & $\begin{array}{l}\text { Heimbach p. Matthias, P.J., Philosophia argumentosa Logica- Fysica, } \\
\text { Coloniae Agrippinae, } 1747 .\end{array}$ \\
\hline $\begin{array}{l}\text { Máyr Phlsophia' Peripathethica } \\
\text { Tom .1 }\end{array}$ & \multirow[t]{4}{*}{$\begin{array}{l}\text { Mayr p. Antonius S.J., Philosophia peripatetica, antiquorum principiis et } \\
\text { recentiorum experimentis conformata, Ingolstadii 1739. (4 svezka) }\end{array}$} \\
\hline Ejusdem. Tom. 2. & \\
\hline Ejusdem. Tom. 3. & \\
\hline Ejusdem. Tom. 4. & \\
\hline Jasklinsky institu'ones logicae. & $\begin{array}{l}\text { Jaszlinszky p. Andreas, S.J., Institutiones Logicae, Viennae et Pragae, } 1750 . \\
(1756 . ?)^{4}\end{array}$ \\
\hline $\begin{array}{l}\text { Prima Elementa Arithm. Algebra, } \\
\text { géom. Trigon. }\end{array}$ & $\begin{array}{l}\text { Prima Elementa Arihmetcae. Algebrae, Geometrae, Trigonometrae planae et } \\
\text { sphericae, Arhitecturae civilis et militaris, Gracii, } 1757 .{ }^{5}\end{array}$ \\
\hline
\end{tabular}

Napomene uz tablicu

1 Ovdje svakako valja istaknuti ogradu zbog nedostatnih odnosno nepreciznih stoga i nedovoljno plauzibilnih podataka, premda postoji vjerojatnost da se doista radi o navedenom djelu, posebice kada se uzme u obzir činjenica kako se ni jedno Senekino djelo ne spominje ni u jednom od kataloga sačuvanih u knjižnici.

2 Pod sadržaj na kataloškom listiću T. Šagi je naveo Hist. Nat. (Historia Naturalis, op.a.) te ga je u katalogu i smjestio $u$ isto predmetno područje.

3 T. Šagi je djelo premjestio pod oznaku Mathesis - Physis- Chimia etc. te je na kataloškom listiću pod sadržaj napisao Physica ispod precrtanog Hist. Nat. (Historia Naturalis, op.a.)

4 Tako je T. Śagi označio na kataloškom listiću, pitajući se o preciznom datiranju djela.

5 Navedeno djelo T. Šagi je premjestio u područje Mathesis - Physis- Chimia etc. te je na kataloškom listiću pod sadržaj naveo samo Mathesis.

Tablični prikaz jasno pokazuje da je 27 djela iz Maccariusova kataloga prisutno i u Šagijevu katalogu te sačuvano u knjižnici. Od 12 izgubljenih primjeraka 9 se tiču prirodoslovno-matematičkog dijela studija filozofije u 18. stoljeću te su do katalogizacije Tomislava Šagija u knjižnici ostale samo 3, koje je T. Šagi još izmjestio iz područja Philosophia u područja Mathesis - Physis- Chimia etc. i Historia Naturalis. S druge strane, nedostatni i šturi podatci iz Maccariusova rukopisa u Šagijevu dobivaju svoju nadopunu- ponajprije puna imena autora i djela, pa mjesto i godinu izdanja.

Ukoliko prihvatimo podjelu povijesti filozofije u kojoj su njeni sastavni dijelovi patristika s apologetikom i skolastika, tada djela i autore s područja filozofije nalazimo i u drugim dijelovima kataloga. Tako su primjerice 3 Tertulijanova djela 
zavedena pod predmetnu oznaku D Authores Predicabiles, Bonaventure i Duns Scota pod h-Minusc: Libri Meditationum, Tome Akvinskog pod O- Theologi Speculativi, 2 naslova M. T. Cicerona pod T. Humanistae te jedno Alberta Velikog pod H Rethores. Na kraju, tu je i 23 djela s područja patristike zavedenih pod predmetnom oznakom B. SS. Patres, među kojima se ističu originalna djela Efrajima Sirijskog ${ }^{30}$ i Aurelija Augustina, ali i Bonaventure i Tome Akvinskog koji nisu živjeli u otačko vrijeme, no ipak im je pridan naslov crkvenih naučitelja. ${ }^{31}$

Tako dolazimo do završne računice, prema kojoj se inicijalnih 39 djela zavedenih pod oznaku $Q$. Philosophi valjaju pribrojati 32 djela zavedena pod ostala predmetna područja, što sveukupno čini 71 knjigu filozofskog karaktera.

\section{KATALOG TOMISLAVA ŠAGIJA IZ 1944.}

Katalog je smješten u ormar s posebnim ladicama (jednom ili više) za svako predmetno područje, koje su dimenzijama prilagođene veličini kataloških listića. Šagi je izvršio najtemeljitiju i najkvalitetniju obradbu knjižnične građe u povijesti knjižnice, kojom je omogućio i izgradio temelje za svaku buduću. Naime, za svaku je pojedinu publikaciju izradio jednu kataložnu jedinicu te kataloški listić. Kataloški listići su kartonski, dimenzija 110×160 mm. Na vrhu listića je masno otisnut i debelo podcrtan natpis „Kapucinska knjižnica u Varaždinu“. Sam listić je sastavljen od dva dijela: lijevi je stupac dvostruko širi i sadrži osam redaka s otisnutim podnaslovima: „Pisac: / Naslov knjige: / Izdanje: / Opaska: /“, dok desni stupac sadrži slijedeće podnaslove: „Sadržaj: / Jezik: / Opaska: /“. Pod spomenute podnaslove, podatke je čistopisom sam i unosio.

Knjižničnu građu Tomislav Šagi je klasificirao u posebna 22 predmetna područja:

"Ascetica / Beletristica / Biblia sacra / Biographia / Cathecetica (et Pedagogica) / Economia / Historia (Geographia et etnologia) / Historia naturalis / Homiletica / Jus canonicum et civile / Lexicographia / Liturgica / Mariologia / Mathesis (physis,chimia etc) / Medicina / Miscellanea / Ordo fratrum minorum Capucinorum / Opera (ota-ss. Patres) / Periodica / Philologia / Philosophia / Sociologia / Theologia /“. ${ }^{32}$

U kataložnom predmetnom području Philosophia nalazi se 157 kataložnih jedinica na 6 različitih jezika. Najzastupljeniji je latinski jezik s 90 djela, potom hrvatski s 28 djela, njemački 24, slovenski 7, grčki 4, talijanski 2 te francuski i srpski s jednim. Gledano prema stoljećima u kojima su izdana, najveći broj djela koje knjižnica sadrži je iz XVIII. stoljeća, što odgovara vremenskom periodu u kojem

\footnotetext{
30 Za Efrem Sirijski (306- 373) vidi Z. TENŠEK, T.Z. PAVIĆ, Patrologija, Kršćanska sadašnjost, Zagreb, 1993., 215. -217.

31 Vidi isto, 2.

32 Katalog Kapucinske knjižnice u Varaždinu (1944.)
} 


\section{Kapuoinska knjižnica u Yaraždinu}

Pisac: 0. Eligins Annamiensis Sadrżaj: Thilosophia

Naslov knjige:

\section{Qursus thilasophi:} ars fristotelico-Som:sticus

Izdanje: Mukopis! I. Maccarius Varasdinensis seristit, Petori: 739

\section{Opaska:}

Jezik: latinsh:

Mjesto: $X X, A \cdot 12$,

Slika 4. Kataloški listić ispisan rukom T. Šagija 1944.

je red kapucina doživio svoj vrhunac, ${ }^{33}$ jednako kao i grad Varaždin koji je bio središte Hrvatske zemaljske vlade (Kraljevsko vijeće za Hrvatsku i Slavoniju) do velikog požara $1776 .^{34}$

Tablica 2. Prikaz broja djela filozofske tematike prema stoljeću izdanja u katalogu iz 1944. Kapucinske knjižnice u Varaždinu.

\begin{tabular}{|l|l|l|l|l|l|l|}
\hline Stoljeće & XV. & XVI. & XVII. & XVIII. & XIX. & XX. \\
\hline Broj djela & 4 & 26 & 26 & 75 & 64 & 71 \\
\hline
\end{tabular}

33 Vidi L. IRIARTE, Povijest franjevaštva, 224. - 231.; M. D’ALATRI, Kapucini. Povijest jedne franjevačke obitelji, 147.

34 Vidi R. HORVAT, Povijest grada Varaždina, 266. - 269. 
Valja posebno naglasiti kako su djela koja se tiču patristike odn. apologetike i skolastike, tradicionalno dio svakog pregleda povijesti filozofije, zavedene u predmetna područja Theologia i Opera (ota-ss. Patres). Štoviše, djela s filozofskom tematikom, njih 109, nalaze se i u drugim područjima: 6 u Biographia, 2 u Homiletica,78 u Opera (ota-ss. Patres), 3 u Ordo fratrum minorum Capucinorum te $16 \mathrm{u}$ Theologia. Također, predmetno područje Periodica sadrži 4 časopisa s nizom objavljenih tekstova filozofske tematike. To su časopisi Bogoslovska smotra ${ }^{35}$, Obnovljeni život, Hrvatska straža ${ }^{36}$, Čas Revija Leonove družbe na slovenskom te Waffender Wahrheit ${ }^{37}$ na njemačkom koji je posvećen Apologetici.

Tako dolazimo do brojke od sveukupnih 266 djela filozofske tematike, od čega ih je 157 smješteno pod predmetnom oznakom Philosophia, a 109 pod ostalim predmetnim oznakama. Među njima, gledajući sadržaj djela, prevladavaju djela koja su vezana uz filozofsko-teološku problematiku. Tako ih je $77 \mathrm{~s}$ područja patristike, uz dodatnih 13 posvećenih isključivo Aureliju Augustinu te 9 apologetike. Skolastike se tiče 19 naslova. Djela opće filozofske tematike ima 35 i ona uglavnom uključuju opće preglede i povijesti filozofije, dok ih je dio posvećen pojedinim filozofskim disciplinama poput Metafizike, Dijalektike i Noetike, s dodatnih 14 različitih Logika. Od klasika antičke filozofske misli knjižnica sadrži po 8 Platonovih i Aristotelovih djela te po 2 Seneke i Cicerona.

Među sačuvanim primjercima kao iznimno vrijedne ističu se tri inkunabule:

1. Seneca Lucius Anneus Cordubensis, (Tarvisii: Bernardum de Colonia, 1478). Naslovni list je otrgnut. ${ }^{38}$

2. s.Aurelius Augustinus hipponensis eppus, Opera omnia (Venetiae: impensis et opera Diyonisii Bertochi de Bolonia, 1491). Naslovnog lista ni u ovoj inkunabuli nema. ${ }^{39}$

3. s.Augustinus Aurelius episcopus Hipponensis, Plura ae diversa sermonum opera (Basileae:Johannes Amberland, 1494). ${ }^{40}$

Također, kao veoma vrijedne treba posebno apostrofirati i dva sačuvana rukopisa:

\footnotetext{
5 Sačuvani su i uvezeni u tvrdi uvez svi brojevi časopisa, počevši od prvog broja iz 1910. godine.

36 Sačuvani su i uvezeni u tvrdi uvez svi brojevi od 1910. do 1919. godine.

37 Izdano u Luzernu, Švicarska- sačuvana su kompletna godišta 1911.-1914.

38 Usp. Tomislav ŠAGI, Katalog Inkunabula i knjiga tiskanih do godine 1536., Knjižnica kapucinskog samostana u Varaždinu, Varaždin, 1944., rukopis, 7. - 8.

39 Isto, 13. - 14.

40 Isto, 20. - 22.
} 
1. p. Eligius Aunaniensis, capucinus, Cursus Philosophicus Aristotelico-Tomisticus, Fr. Maccarius Varasdinensis scripsit, Petrovii, $1739 .{ }^{41}$

2. Jacquier Franciscus (Ord. Minimorum s.Francisci de Paulo), Institutiones philosophicae (Venetus, 1767), svezak uvezen u pergamenu.

Za razliku od kataloga Maccariusa Varasdinensisa iz 1762., gdje su djela filozofske tematike prikupljana u svrhu provođenja studija filozofije, Šagijev katalog nema takva specifična objašnjenja za prikupljenu građu s područja filozofije, premda i današnji petogodišnji studij teologije također, u znatnoj mjeri, uključuje filozofsku naobrazbu te, štoviše, nosi naziv Filozofsko-teološki studij ${ }^{42}$. Knjižnica i njen fond svakako služe i koriste i za takve svrhe, no isto tako i kao pripomoć u svakom znanstvenom i inom radu kako redovnicima i svećenicima u samostanu i provinciji, tako i svima ostalima. Najpreciznije bi bilo ustvrditi kako je knjižnica, sa svojom kroz stoljeća prikupljanom građom, dio šireg kulturnog i intelektualnog nasljeđa i baštine.

\section{DJELA HRVATSKIH AUTORA}

Kako Maccarius u katalogu iz 1762. ne navodi ni jedno filozofsko djelo hrvatskog autora ili na hrvatskom jeziku, preostaje okrenuti se katalogu Tomislava Šagija. Tako, najstarije sačuvano djelo filozofske tematike nekog hrvatskog autora u samostanskoj knjižnici jest rukopis Maccariusa Varasdinensisa na latinskom jeziku Cursus Philosophicus Aristotelico-thomisticus. In lucem datus a R.P. Eligio Annanicensi Capue. Conscriptus a V. Fr. Maccario Varasdinensi eiusdem instituti studioso. (Petovÿ, 1739). Uz ovo, sačuvana su još tri djela pisana latinskim jezikom s polovice 18. stoljeća, za koje Šagi na kataloškim listićima donosi sljedeće podatke: „Paulachich, Petrus Aloysius, Croata carlostadiensis, Assertiones ex universa Philosophia in S.J. Academia Zagrabiensi publice propuguatae, Zagrabiae, 1759. (uvezeno sa Series banorum)“; „Milčić Antonius Carlostadiensis Croata, Assertiones ex universa Philosophia in S.J. Academia Zagrabiensi publice propuguandae, Zagrabiae, 1754. (uvezeno s Collegium magistri)“ i „Krajačić Marcus, phil. ex praelect. Šimunić Joań.. Bapt. S. J., Assertiones

41 Bono Zvonimir ŠAGI, Rukopisi Kapucinske knjižnice u Varaždinu, Kapucinski samostan u Varaždinu, Varaždin, 2001. (nije objavljeno), donosi tekst: „MAKARIJE, iz Varaždina, profesor filozofije i teologije, pisac, propovijednik (Varaždin, - Varaždin, 2. I. 1783). U KR stupio 15. I. 1736. Ostavio je u rukopisu slijedeća djela koja se nalaze u samostanskoj biblioteci u Varaždinu: Cursus Philosophicus Aristotelicothomisticus. In lucem datus a R.P. Eligio Annanicensi Capue. Conscriptus a V. Fr. Maccario Varasdinensi eiusdem instituti studioso. Pisano god. 1735. To je uglavnom prepis i prilagodba ogromnoga Eligijevog djela...", 2.

42 Vidi http://www.kbf.unizg.hr/studiji/filozofsko-teoloski_studij/ (pristup, 13. 11. 2015. u 10.44). 
ex universa Philosophia in S.J. Academia Zagrabiensi, Zagrabiae, 1759. (uvezano s De incertitudine scientiarum)".

Najstarije djelo na hrvatskom jeziku je Platon, Kriton, Hiparh, sa žitjem Platona (preveo I.V.Kostić, Osijek) iz 1862. godine. Ipak, ono najvrjednije što knjižnica čuva jesu originalna djela hrvatskih filozofa s početka i prve polovice 20. stoljeća. Među njima ističe se 10 naslova Stjepana Zimmermanna: Logika I. dio: Dijalektika i Logika II. Dio Kritika ili Noetika (1905); Opća Noetika (1918); Opća Metafizika ili Ontologija (1918, zajedno s A.Bauerom); Psihologija (1928, udžbenik za srednja učilišta); Temelji filozofije, Historijsko-kritička orijentacija (1934); Religija i život (1938); Filozofija i religijaFilozofijske istine o Bogu i čovjeku: Razumni temelji vjere (1941); Filozofija i religija (1941); Kriza kulture, Filozofija života (1943); Kulturno filozofijske studije iz suvremene socialne filozofije (1943). Također, tu je i 6 naslova Josipa Stadlera: Logika (1905); Opća metafizika ili Ontologija (1907); Kosmologija (1909); Psihologija (1910). Potom, ovdje su i po 3 naslova Ante Bauera: Naravno bogoslovlje, ili koliko može čovjek samik razumom spoznati Boga (1892); Opća metafizika ili Ontologija (izd. 1894 i izd. 1918), potom Franje Šanca: Stvoritelj svieta, njegova egzistencia i naravni Njegov odnos prema svietu (1935); Povijest filozofije I.dio (1943); Povijest filozofije II.dio (1943) i Hijacinta Boškovića, dominikanca: Sv. Toma Akvinski i Duns Scott (1940); Nove struje u modernoj filozofiji (1934) te izdanje Maritain Jacques (s francuskog preveo V.Paljak), Anđeoski Naučitelj za koji je napisao predgovor o Skotizmu. Naposljetku, sačuvano je i po 1 djelo Alberta BazalePoviest filozofije (1908), Alberta Halera- Doživljaj ljepote (1943) i Vilima KeilbachaParapsihologija i religija-okultizam i spiritizam u svietlu novijih naučnih istraživanja (1944). Također, vrijedno je istaknuti i predgovor Vladimira Filipovića izdanju Platon, Država, Državnik, VII: pismo (prijevod Martin Kuzmić, Gortan Veljko, Gašparović) iz 1942., te zbirku pjesama Izabrane pjesme Đure Arnolda iz 1923.

\section{ZAVRŠNI OSVRT}

Provedeno istraživanje u samostanskoj knjižnici reda Kapucina u Varaždinu, pregled i predstavljanje do sada neobrađenih i neobjavljenih kataloga, nepobitno dokazuju prisutnost djela filozofske tematike u ukupnom knjižničnom fondu. Tako, katalog Maccariusa Varasdinensisa iz 1762. sadrži popis 39 knjiga smještenih pod predmetnu oznaku Q. Philosophi te još 32 djela filozofskog karaktera smještenih pod druge predmetne oznake- sveukupno 71. Kolikoća i kakvoća prikupljene građe filozofskog karaktera je ponajprije i uglavnom određena ulogom filozofije unutar obligatornog petogodišnjeg studija za svećeničke i propovjedničke kandidate, zbog čega popis 39 djela prati potrebe kurikuluma studija ustrojenog prema odlukama Ordinacija reda iz 1757. godine. 
S druge strane, Šagijev katalog iz 1944. sadrži 157 primjeraka smještenih pod područje Philosophia, odnosno ukupnih 266 ako se pridodaju djela sadržana pod ostalim predmetnim oznakama, uz jednu bitnu razliku spram Maccariusova kataloga- njihov udio više nije vezan samo uz potrebe studija.

Paralelnom usporedbom dvaju kataloga je ustanovljeno kako je 27 djela s Maccariusova popisa i dalje sačuvano u Šagijevom katalogu odnosno u današnjoj knjižnici. U sadržajnom smislu, najveći dio djela u oba kataloga tiče se tema općeg filozofskog karaktera: suma, pregleda i udžbeničke građe, često posvećene jednoj ili više filozofskih disciplina (logici, metafizici i slično). S druge strane, podatci koje sadržava Šagijev katalog omogućuju uvid u broj djela po stoljećima izdanja te jeziku na kojem su napisana. Pokazalo se da je najviše izdanja iz 18. stoljeća, u vrijeme vrhunca razvoja kako kapucinskog reda, tako i grada Varaždina. Više od polovice sačuvanih djela je pisano na latinskom, a među njima se posebno se ističu tri inkunabule i dva rukopisa. Također, knjižnica čuva i manju zbirku djela hrvatskih filozofa prve polovice 20. stoljeća pisanih na hrvatskom jeziku.

Šagijeva je katalogizacija prijelomna točka povijesti knjižnice. U prvom redu jer je obradbu građe Šagi izvršio vrlo temeljito i izuzetno pedantno, uz iznošenje velike količine do tada nezavedenih podataka o prikupljanoj građi. U drugom redu poradi vršenja klasifikacije građe u 22 područja. U trećem redu, kao ono najvažnije zbog izrade kataložnih jedinica i pripadajućih kataloških listića za svaku pojedinu publikaciju. Na taj je način utemeljio i omogućio svaku daljnju katalogizaciju, istraživanje i budući razvoj knjižnice.

\section{LITERATURA}

1. Constitutioni De Fratri Minori Capuccini di S. Francesco, Aprouate, e confermate da N S Papa Urbano VIII, Nella Stamparia della Reuer.Cam.Apost., Roma, 1643., prvo izdanje; Constitutiones, ordinis fratrum minorum Capuccinorum, decursu promulgatae, vol.I Constitutiones antiquae (1529.-1643.), Curia generalis OFMCap., Romae, 1980.

2. Mariano D'ALATRI, Kapucini. Povijest jedne franjevačke obitelji, Verbum, Zagreb, 2010.

3. Lazaro IRIARTE, Povijest franjevaštva, Kršćanska sadašnjost, Zagreb, 2013.

4. Mirko KEMIVEŠ, „Dolazak kapucina u Varaždin i znameniti kapucini tijekom 300 godina varaždinskog samostana", Radovi Zavoda za znanstveni rad HAZU Varaždin, br. 12-13/2001, 123. - 146.

5. Maccarius Varasdinensis, Catalogus alphabeticus librorum Conventus Varasdinensis ab Anno MDCCLXII., Kapucinski samostan Varaždin, Varaždin, 1762., rukopis. 
6. Necrologium provincialis, Hrvatska kapucinska provincija sv. Leopolda Bogdana Mandića, Zagreb, 2013.

7. Nekrologij slovenskih in hrvaških kapucinov, Interno izdanje slovenskih kapucina, Ljubljana, 1977.

8. Tomislav Janko ŠAGI-BUNIĆ, Redovnička zajednica kojoj je pripadao sluga Božji o. Leopold Bogdan Mandić, Kršćanska sadašnjost, Zagreb, 1976., 386. - 389.

9. Bono Zvonimir ŠAGI, „Kapucinska knjižnica u Varaždinu“, Radovi Zavoda za znanstveni rad HAZU Varaždin, br.8-9/1996, 103. - 109.

10. Bono Zvonimir ŠAGI, „Pastoralna djelatnost kapucina u Varaždinu“, Radovi Zavoda za znanstveni rad HAZU Varaždin, br.12-13/2001., 165. - 174.

11. Bono Zvonimir ŠAGI, Rukopisi Kapucinske knjižnice u Varaždinu, Kapucinski samostan u Varaždinu, Varaždin, 2001., nije objavljeno.

12. Tomislav ŠAGI, Katalog Inkunabula i knjiga tiskanih do godine 1536., Knjižnica kapucinskog samostana u Varaždinu, Varaždin, 1944., rukopis.

13. Jure ŠARČEVIĆ, „Dolazak kapucina u Varaždin“, Radovi Zavoda za znanstveni rad HAZU Varaždin, br.12-13/2001, 115. - 121.

14. Zdenko TENŠEK, „Kapucini, katolički red u svijetu i kod nas“, Radovi Zavoda za znanstveni rad HAZU Varaždin, br.12-13/2001, 105. - 114.

15. T. Z. TENŠEK, J. PAVIĆ, Patrologija, Kršćanska sadašnjost, Zagreb, 1993.

\section{SAŽETAK}

\section{UDIO DJELA S FILOZOFSKOM TEMATIKOM U KNJIŽNOM FONDU SAMOSTANSKE KNJIŽNICE REDA KAPUCINA U VARAŽDINU PREMA KATALOZIMA IZ 1762. I 1944.}

Dolazak reda Kapucina u Varaždin datira se u godinu 1699., kada je došlo i do osnivanja samostana te pripadajuće knjižnice, sukladno Konstituciji Ordo Fratrum Minorum iz 1643. kako „u svakom samostanu mora biti srednje velika soba određena za knjižnicu“. Izvorni prostor knjižnice danas više nije u funkciji, već se nalazi na četiri odvojene lokacije unutar samostana.

Prvu katalogizaciju do tada prikupljene knjižnične građe izvršio je varaždinski kapucin Maccarius Varasdinensis 1762. godine. U sačuvanom rukopisu naslovljenom Catalogus alphabeticus librorum Conventus Varasdinensis ab Anno MDCCLXII građu je klasificirao u 27 predmetnih područja. Filozofska djela, njih 39, smjestio je pod oznaku Q. Philosophi.

Najvažniju katalogizaciju detaljnom inspekcijom i obradbom građe izvršio je Tomislav Šagi 1944. godine. Štoviše, za sve sačuvane publikacije izradio je kataloške jedinice i pripadajuće kataloške listiće sa sljedećim relevantnim podatcima: pisac / naslov knjige / izdanje / 
opaska / sadržaj / jezik / mjesto /. Upravo rukom ispisani listići temelj su svake daljnje katalogizacije i razvoja knjižnice, kao i mogućih istraživanja.

Nakana autora je na temelju dva kataloga istražiti udio knjiga s filozofskom tematikom u knjižnom fondu knjižnice Kapucinskog samostana u Varaždinu. Cilj je precizno utvrđivanje kolikoće i kakvoće specifične knjižnične građe, kako s obzirom na sadržaj djela, tako i na jezik, godište i vrstu izdanja, gdje se posebice želi utvrditi je li u pitanju inkunabula ili rukopis.

Naposljetku, autor posebno apostrofira djela hrvatskih autora, među kojima se kolikoćom ističu Stjepan Zimermann, Josip Stadler, Franjo Šanc, Ante Bauer i Hijacint Bošković.

Ključne riječi: filozofija; Katalog kapucinske knjižnice u Varaždinu iz 1762. i 1944.; Maccarius Varasdinensis; Tomislav Šagi.

\section{SUMMARY}

\section{SHARE OF PHILOSOPHICAL TITLES IN THE LIBRARY FUND OF THE VARAŽDIN CAPUCHIN MONASTERY LIBRARY ACCORDING TO THE 1762 AND 1944 CATALOGUES}

The Order of Capuchin Friars came to Varaždin in 1699, when they established the monastery. The decision to build the Monastery Library was consistent with the Constitution of the Ordo Fratrum Minorum dating from 1643: "In every monastery there should be a middlesized room designated for a library". Present library is placed in four separate locations in the monastery, while the original one doesn't exist any more.

The first cataloging of the library fund was made by the Varazdin's Capuchin Maccarius Varasdinensis in 1762. In manuscript entitled Catalogus alphabeticus librorum Conventus Varasdinensis ab Anno MDCCLXII, Maccarius classifies library fund in 27 subject areas. Under the area $Q$. Philosophi he locates 39 philosophical titles.

The most significant cataloging in the monastery history, is made by capuchin friar Tomislav Sagi in 1944. Sagi conducted a detailed inspection of the library fund. Moreover, he made the catalog cards for each publication, containing following relevant data: the writer / the book title / the release date / the special remark / the content / the language / the library location. Thereby, he enabled and established all further development of the library, as well as possible research.

The author's intention is, by using two catalogues, to determine the amount of books with philosophical topics present in the Library fund of the Varaždin Capuchin Monastery Library . The goal is to accurately determine the amount of specific bibliographical items, with regard to the content, language and release date, as well as the type of publication- whether is a manuscript or incunabula.

Finally, the author emphasizes works of Croatian authors: Stjepan Zimermann, Josip Stadler, Franjo Šanc, Ante Bauer and Hijacint Boskovic.

Key Words: Philosophy; Varaždin Capuchin Monastery Library Catalog from 1762 and 1944; Maccarius Varasdinensis; Tomislav Šagi. 